\title{
The influence of music therapy on quality of life after a stroke
}

\section{BACKGROUND}

A stroke is an interruption in the course of one's life. It often results in physical disability, cognitive or executive disorders, emotional problems and, as a consequence, the decrease of one's quality of life. The goal of this research was to determine whether music therapy during neurorehabilitation can positively influence the assessment of one's quality of life after a stroke.

\section{PARTICIPANTS AND PROCEDURE}

Sixty-one people who had had strokes and were in the early stages of neurorehabilitation in a hospital took part in the research ( $n=31$ in the control group and $n=30$ in the experimental group). All of them were physically disabled and had either minor cognitive and executive disabilities or none at all. People were randomly assigned to groups. Those in the experimental group participated in a one-onone music therapy programme divided into 10 sessions based on guided imagery music therapy and cognitive music therapy. The first measurement of quality of life took place at the beginning of the hospital stay at the department of neurorehabilitation (about 1 month after the stroke) and the second took place about 1.5 months later.
RESULTS

Analysis of the results showed that participation in the music therapy programme was associated with a higher assessment of quality of life in the following aspects: general health, vitality, mental health, communication, emotional condition, and alertness. However, taking part in the music therapy had no influence on the assessment of quality of life in the areas of pain, limitation of social roles, relationships, self-care, mobility, and taking care of the house.

\section{CONCLUSIONS}

Stroke survivors who took part in music therapy assess their quality of life as higher compared to patients who did not take part in music therapy.

Music therapy could constitute a supplementary method of treatment for patients during neurorehabilitation after a stroke, thus improving their quality of life.

\section{KEY WORDS}

music therapy; stroke; health-related quality of life; neurorehabilitation 


\section{BACKGROUND}

Stroke is a frequent cause of motor disability (Szczudlik, Członkowska, Kwieciński, \& Słowik, 2007; Poćwierz-Marciniak \& Bidzan, 2015), as well as the impairment of cognitive and executive functions (Turaj, 2007). The inability to fulfil previous life roles as well as changes in interpersonal relations further worsen the emotional state of the affected individual. Depression is a frequent problem (Kwok et al., 2006; Carod-Artal, Egido, Gonzales, \& de Seijas, 2000;

Ilona PoćwierzMarciniak, Mariola Bidzan
Haghgoo, Pazuki, Hosseini, \& Rassafiani, 2013; Oros, Popescu, Iova, Mihancea, \& Iova, 2016; Shi et al., 2016). All this causes a decrease in the quality of life of individuals affected by strokes (Jaracz \& Kozubski, 2006; Carod-Artal, Trizotto, Ferreira-Coral, \& Menezes-Moreira, 2009; Sheldenkar et al., 2014).

\section{QUALITY OF LIFE POST-STROKE AND ITS DETERMINANTS}

Health-related quality of life (HRQL) is usually defined as a functional effect of illness and its treatment as perceived (experienced) by a patient, and refers to an individual's perception of their physical and mental state, as well as their social position (Schipper, 1990). According to de Walden-Gałuszko (1997), HRQL could be defined as an assessment of one's own life situation made during illness and treatment, taking into account the special role of the illness and treatment. It is particularly important for the ability to learn about the well-being of specific patients or groups of patients as well as for estimating gains and losses associated with medical interventions (Kiebert, 1997).

Health-related quality of life is lowered after stroke (Jaracz \& Kozubski, 2006; Carod-Artal et al., 2009; Sheldenkar et al., 2014). Some of the frequently listed determinants of HRQL are as follows: age, sex, type and side of stroke, time since stroke, severity of stroke, functional state, as well as cognitive and executive dysfunctions (Chou, 2015; Carod-Artal et al., 2009). Lower assessment of quality of life and slower changes in its assessment 2 years after the stroke are prompted by factors such as older age, gender (women assessed their quality of life lower than men) and lower levels of education (Chen, Ran, Liu, Zhao, \& Zhu, 2015a). Also of importance are the extent and type of brain damage (Shi et al., 2016; Chou, 2015), as well as the associated physical inability (Min \& Min, 2015), resulting in dependence on others (Van Mierlo et al., 2016). These are central determinants of quality of life. So, the higher the level of disability and the higher the dependence on caregivers, the lower the quality of life (Shi et al., 2016; Chou, 2015; Min \& Min, 2015; Van Mierlo et al., 2016).

One of the many consequences of stroke is depression, and it significantly lowers HRQL (Kwok et al., 2006; Carod-Artal et al., 2009; Haghgoo et al., 2013; Oros et al., 2016; Shi et al., 2016). Depression is a result of disability (Shi et al., 2016) and the associated dependence on others in everyday functioning (Oros et al., 2016). Research suggests that symptoms of depression experienced a month after stroke correlate with lower long-term assessment of HRQL: at 3 months (Guajardo et al., 2015) or 7 months after stroke (Visser et al., 2015). Researchers stress that psychological support and treatment of depression can significantly increase HRQL (Chen et al., 2015b; Chou, 2015).

Cognitive function impairments are undoubtedly of great importance for the assessment of HRQL after a stroke. Presence of these impairments 3 months after a stroke is associated with lower HRQL assessment measured one year after the stroke. The strongest relationship was shown with regards to attention and visuospatial impairments (Cumming, Brodtmann, Darby, \& Bernhardt, 2014). The role of problems in visual perception in the assessment of HRQL among stroke patients was also confirmed in Norwegian research in which $25 \%$ of subjects reported vision problems. They were characterised by lower assessments of quality of life (probably their vision problems also resulted in higher levels of disability) (Sand, Naess, Midelfart, Thomassen, \& Hoff, 2016). However, in a Taiwanese study measuring the determinants of HRQL after a stroke, the impact of cognitive function impairments on the quality of life assessment was not as strong as the impact of physical factors associated with the depth of brain damage, as well as psychosocial determinants (Chou, 2015).

From the perspective of searching for the determinants of quality of life after a stroke, it seems interesting to ask whether personality features may influence its assessment. Personality problems, including increased neuroticism, are moderately related to lower assessment of HRQL perspectives, whereas coping, internal locus of control, sense of self-worth, hope, and optimism are moderately positively correlated with HRQL, and extrovertedness does not have a relationship with HRQL (Van Mierlo et al., 2014). Undoubtedly, the ability to cope in difficult situations, such as everyday functioning with the consequences of stroke, and the ability to positively solve problems are associated with higher quality of life, which was proved by the Dutch team of researchers led by Visser (Visser et al., 2015). Strategies of active coping are associated with higher quality of life not only in post-stroke individuals, but also among older individuals in general (Gamrowska \& Steuden, 2014).

Literature research gives no clear answer about which of the listed factors has the biggest influence on the assessment of HRQL. Comparison of determinants of post-stroke HRQL in two countries, Germany and Nigeria, conducted by Owolabi (2013), 
showed that, despite the very different cultures, marital status and type of stroke did not correlate with HRQL, while the severity of stroke, disability, emotional disorder and sense of purpose in life predicted quality of life. In turn, in a British study conducted by a team led by Ayis (Ayis et al., 2015), comparing 5 European populations (from France, Lithuania, the UK, Poland, and Italy) with regards to survival rates it was found that in included populations, despite significant differences in survival rates, there was a strong relationship between HRQL assessed three months after stroke and survival rates within the first year after stroke. The higher the quality of life, the higher was the probability of survival.

It is worth mentioning here the results of German research by Katona and colleagues, who suggested that the higher the HRQL directly after releasing patients from hospital after a stroke, the higher its levels are one and 2.50 years later (Katona, Schmidt, Schupp, \& Graessel, 2015). In order to improve physical ability and, thus, improve the quality of life, physical therapy is used. Improving a person's psychological state is equally as important for post-stroke HRQL improvement. In this context, it is interesting to know whether music therapy could serve such a role.

\section{MUSIC THERAPY AND QUALITY OF LIFE}

The World Federation of Music Therapy defines music therapy (MT) as "the use of music and/or its musical elements (sound, rhythm, melody and harmony) by a music therapist, and client or group, in a process designed to facilitate and promote communication, relationship learning, mobilisation, expression, and organisation (physical, emotional, mental, social and cognitive) in order to develop potentials and develop or restore functions of the individual so that he or she can achieve better intra- and/or inter-personal integration and, consequently, a better quality of life" (Ruud, 1997). There is a lot of research suggesting the positive effects of MT in various groups of patients: with pain (Kamioka et al., 2014), stress and anxiety (Schou, 2014; Metera, 2002; Mielnik \& Mielnik-Matityahu, 2013), and cardiology patients (Doğan \& Şenturan, 2012; Bradt \& Dileo, 2009). The efficacy of MT in attaining a higher level of the quality of life was the most widely documented in groups of oncology patients (Burns, 2001; Bonde, 2004; Bozuk, Artac, Kara, Ozdogan, \& Sulp, 2006; Joske, Rao, \& Kristjanson, 2006; Stańczyk, 2010, 2012).

There is decidedly less discussion about the impact of MT on quality of life for neurology patients, despite the fact that MT is increasingly being used in neurorehabilitation. In neurology and neurological rehabilitation MT is used as an adjunctive form of therapy during various stages of treatment. The concept of neurological MT includes using MT in sensorimotor rehabilitation and cognitive function therapy, including language functions. The subject literature throughout the world since the 1980s has been describing positive results achieved with MT methods (such as singing popular songs, or group improvisation) in paediatric rehabilitation (Kennelly \& Brien-Elliot, 2001), adults in comas or with post-injury amnesia (Aldridge, Gustorff, \& Hannich, 1990; Gilbertson, 2005; Tamplin, 2000) as well as speech rate, articulation and intonation problems for persons with neurogenic communication disorders (Cohen \& Masse, 1993; Tamplin, 2005). Additionally, rhythmic auditory stimulation effects in physiotherapy and gait training were analysed (Thaut, 1999; Paul \& Ramsey, 2000; Hurt \& Thaut, 2009; Bukowska, 2012). In Parkinson's disease it has been proven that music-based movement therapy, i.e. the rehabilitation of mobility while listening to music, is effective in the improvement of gait and other activities which depend on the ability to walk; however, interestingly, its role in the assessment of quality of life has not been shown (de Dreu, van der Wilk, Poppe, Kwakkel, $\&$ van Wegen, 2012). The effects of MT are also used in the rehabilitation of upper limbs (Tong et al., 2015) and appropriately selected music training is used in cognitive impairments (Baker \& Tamplin, 2006; Bukowska, 2012).

There is clearly less interest in the role of MT in emotionally coping with suddenly acquired motor disability, though also here researchers make some interesting points. For example, Baker and Tamplin (2006) describe the positive influence of songwriting and improvising on a patient's emotions after sudden brain injuries, in order to work through the trauma, look into one's own feelings, cope with current problems in rehabilitation and for an optimistic outlook for the future. In order to improve psychosocial behaviours, Music Psychotherapy and Counselling is used; it involves bolstering emotional expression and acquiring increased awareness of one's own psychosocial behaviours through guided music listening, expressive improvisation or musical role playing. For instance, a patient may learn to unload their anger and cope with tension through playing drums (Thaut, 2005; Baker \& Tamplin, 2006). It is also known that MT improves the mood of patients with acquired brain lesions (Thaut, 1989) and it reduces anxiety (McKinney, 1990). Research by Purdie's team (Purdie, Hamilton, \& Baldwin, 1997) found that the improvement of communication skills and psychological condition of patients taking part in MT was close to the threshold of statistical significance. MT patients played popular compositions and improvised on percussion instruments or with their own voices in 12 weekly sessions lasting for about 30 minutes each. A similar result in the realm of mood, as well as a significant increase in social interactions and en-
Music therapy after a stroke 
Ilona PoćwierzMarciniak, Mariola Bidzan gagement in therapy was observed in the study by Nayak, Wheeler, Shiflett and Agostinelli (2000). Here, brain injury patients took part in a maximum of 10 sessions in which they sang and composed songs, played instruments, improvised, as well as listened to music two or three times a week during hospitalisation. Research by Jeong and Kim (2007), in which the main aim of MT was to improve the motor functions of individuals who experienced stroke through rhythmic auditory stimulation, showed not only an improvement in ability to walk and the smoothness of gait, but also a statistically significant improvement in mood and interpersonal relations. Other interesting conclusions were reached by Särkämö et al. (2008). In this study 60 stroke patients were randomly assigned to three groups: one in which patients listened to music for one hour every day for two months, one in which subjects listened to audiobooks every day, and a control group of subjects who did not receive any listening materials. In the music listening group a significant improvement was observed with regards to verbal memory and ability to focus attention, together with lower levels of depression and decreased mood. The authors suggested that these positive changes are possible due to the engagement of many mechanisms in the brain that take part in processing music. These results were replicated by Forsblom, Särkämö, Laitinen, and Tervaniemi (2010), in a study in which stroke patients listened to either music or audiobooks for one hour a day for 2 months. Here, again, the group listening to music received better outcomes in regards to mood, relaxation, and motor activity.

From the perspective of the importance of MT for lowering levels of depression in individuals who have experienced a stroke (as mentioned before, depression is one of the more frequent consequences of stroke), it is worth mentioning research by Kim et al. (2011). Patients attended 40-minute group sessions twice a week for a period of 4 weeks. These sessions started with a song and sharing experiences from everyday life, then various musical activities were performed, and at the end a goodbye song was sung and participants shared their feelings associated with the session. After the programme finished, it was found that levels of depression were significantly lowered among MT participants, and that a lowering of levels of anxiety was on the threshold of statistical significance. Also, Van Vugt, Ritter, Rollnik, and Altenmüller (2014) observed lower levels of depression for individuals who received active MT which consisted of playing finger exercises and simple children's songs on a piano during ten 30-minute sessions. Moreover, a decrease in the levels of tiredness and an increase of synchronisation during clapping were observed. An improvement of mood caused by active MT in the form of stretching exercises with music, singing songs, and playing percus- sion instruments was observed also in a study by Jun, Roh, and Kim (2012), in which an increase in levels of shoulder and elbow joint flexion was also observed. A similar mood improvement effect, and an increase in arousal, was documented by Chen, Tsai, Huang, and Lin (2013). Stroke patients were given the task of listening to self-chosen music that was either pleasant or unpleasant. As one might expect, an increase of arousal and mood improvement took place after listening to pleasant music.

However, a great majority of the research on MT concentrates on the results of using music in the rehabilitation of motor and cognitive functions (Thaut, 2005; Baker \& Tamplin, 2006; Sena-Moore, 2013), not only among stroke or brain injury patients (Bukows$\mathrm{ka}, 2012$ ), but also in dementias of varying aetiologies (Vink, Bruinsma, \& Scholten, 2013). A summary of systematic reviews of randomised controlled studies regarding the efficacy of MT in different areas of medicine (Kamioka et al., 2014) showed that only studies analysing the positive effects of MT on the improvement of quality of gait, balance, and muscle tension when attempting to move fulfilled the criteria of random group selection (Bradt, Magee, \& Dileo, 2010). Data from analyses of the influence of MT on other aspects of acquired brain injury patients functioning are, according to the authors, insufficient for drawing reliable conclusions (Kamioka et al., 2014).

The impact of MT on HRQL in stroke patients is not fully explored, and the mechanisms of potential improvement of HRQL are not fully described yet. It is likely that MT approaches that concentrate on motor functions may influence quality of life through improving motor ability and may be associated with lower dependence on others. In turn, MT approaches that focus on the improvement of psychological state may improve the HRQL through: mood improvement, bolstering the levels of energy, vitality, as well as the ability to work through traumatic experiences (Szulc, 2011).

The rationale to undertake this research was that there are no studies measuring the influence of MT on HRQL in post-stroke patients in Poland. The aim of this study was to assess the efficacy of an MT programme on HRQL in post-stroke patients undergoing rehabilitation. It was assumed that HRQL would increase with time elapsed since the stroke, but that the improvement would be more visible in patients who additionally take part in MT.

\section{PARTICIPANTS AND PROCEDURE}

The study was designed as a randomized controlled trial, where participants were allocated to two conditions: intervention group (IG) vs. standard care (SC). Allocation was based on a computerized random-number generator. All participants were in- 
formed about the aims and the design of the study, and they gave consent to take part in the study.

We included 61 individuals affected by strokes who were undergoing neurological rehabilitation in Gdynia (Northern Poland). The 30 patients were randomised to the intervention group (IG) and 31 to the control group (CG). The inclusion criteria were as follows: 1) First episode of stroke (ischaemic or haemorrhagic); 2) Presence of a motor disability; 3) Absence of evident cognitive or executive disorders; 4) A score of $\geq 27$ points on the Mini-Mental State Examination (Folstein, Folstein, \& McHugh, 1975); 5) A score of $\geq 16$ points on the Frontal Assessment Battery (Dubois, Slachevsky, Litvan, \& Pillon, 2000). Individuals from IG additionally took part in 10 individual MT sessions. All patients, both in IG and CG, were undergoing an inpatient neurological rehabilitation in hospital, and they received standard care, which included physiotherapy, ergotherapy, psychological diagnosis, and maintenance psychotherapy.

Statistical analyses were conducted using twoway repeated measures ANOVA, with the factors being time of measurement (at the beginning vs. at the end of rehabilitation) and group (music therapy intervention group vs. control group).

\section{METHODS}

The first measurement of HRQL took place about 1.50 months after stroke, and the second measurement about 3 months after stroke. Between measurements, individuals from IG took part in 10 one-byone MT sessions about twice a week across a period of 5 weeks. Data from the participants were collected by a researcher (first author). HRQL was evaluated by using three independent measurements, which together give a full picture of the quality of life evaluation. These were:

The Medical Outcome Study 36-Item Short-Form Health Survey (SF-36), which includes the following subscales: physical functioning, role limitations due to physical health, bodily pain, general health perceptions, vitality, social functioning, role limitations due to emotional health, and mental health (Ware \& Sherbourne, 1992; Tylka \& Piotrowicz, 2009).

The Stroke-Adapted 30-Item Version of the Sickness Impact Profile (SA-SIP30), a shorter version of the Sickness Impact Profile adapted for stroke patients, composed of the following subscales: body care and movement, social interaction, mobility, communication, emotional behaviour, household management, alertness behaviour, and ambulation (Van Straten, de Hahn, \& Limburg, 1997).

The Cantril Ladder, an 11-point Likert scale where a subject indicates their current quality of life, quality of life before the illness and the expected quality of life in 3 years (Cantril, 1965).

\section{MUSIC THERAPY PROGRAMME}

The programme used in the study, developed by the authors, comprised a one-on-one session by using mainly a receptive approach (Poćwierz-Marciniak, 2014; Nowak, Bidzan, Śniegowski, \& Cieśla, 2014). It was based on cognitive MT and Guided Imagery and Music (Bonny, 2002). This model assumes that music, through the activation of certain imagery, stimulates certain emotions and memories that need to be worked through. The combination of music and words allows one to re-experience and analyse difficult content, and in doing so minimize its detrimental influence on daily functioning (Stachyra, 2012). Classical and film music compositions were used.

The programme aims to achieve short-term effects such as improvement of current mood, an increase in the sense of joy and levels of energy, musical activation, and minimisation of psychophysical tension. Long-term effects included a higher degree of acceptance of the illness and coping with pain, the strengthening of an internal sense of control over one's own health through active rehabilitation and prophylaxis of stroke relapse, becoming aware of experienced emotions and better handling of difficult emotions, as well as determining one's own role in social relations and proper functioning in those roles, which should improve one's quality of life.

The one-on-one MT session, taking place about twice a week, was identical for each patient, and involved 10 meetings which followed the same pattern. Each session was divided into three parts: an introduction, which involved describing the patient's current mood and doing breathing exercises while listening to music or using their voice; the main part, including addressing the session's main theme while listening to music, conversation and psychoeducational activities as well as MT exercises; and the final part, which consists of relaxation while listening to music and a summing-up of the conversation.

Themes addressed in subsequent sessions were preceded by an introductory class, and were grouped into three cycles: "Around the illness", "Around emotions" and "Around interpersonal relations" (Poćwierz-Marciniak, 2014; Nowak et al., 2014). Music therapy was led by a researcher (first author) who is a trained music therapist.

\section{RESULTS}

We included 61 subjects between age 44 and 84 (mean $=64$ years), 29 men and 32 women. Groups were matched in terms of sex, stroke locus and the type of stroke. Detailed characteristics of the investigated groups are presented in Table 1.
Music therapy after a stroke 
Table 1

Characteristics of participant groups

\begin{tabular}{|c|c|c|c|c|c|c|c|c|c|c|}
\hline & \multicolumn{2}{|c|}{$\begin{array}{c}\text { Total } \\
(N=61,100 \%)\end{array}$} & \multicolumn{2}{|c|}{$\begin{array}{c}\text { Control group } \\
(n=31,50.80 \%)\end{array}$} & \multicolumn{2}{|c|}{$\begin{array}{c}\text { Intervention } \\
\text { group } \\
(n=30,49.20 \%)\end{array}$} & \multicolumn{4}{|c|}{ Comparison of distributions } \\
\hline & $n$ & $\%$ & $n$ & $\%$ & $n$ & $\%$ & $\chi^{2}$ & $d f$ & $p$ & $\mathrm{Cc}$ \\
\hline \multicolumn{11}{|l|}{ Sex } \\
\hline Men & 29 & 47.50 & 15 & 48.40 & 14 & 46.70 & 0.00 & 1 & .999 & .02 \\
\hline Women & 32 & 52.50 & 16 & 51.60 & 16 & 53.30 & & & & \\
\hline \multicolumn{11}{|l|}{ Stroke locus } \\
\hline Right hemisphere & 36 & 59.00 & 18 & 58.10 & 18 & 60.00 & 0.03 & 2 & .987 & .02 \\
\hline Left hemisphere & 23 & 37.70 & 12 & 38.70 & 11 & 36.70 & & & & \\
\hline Brain stem & 2 & 3.30 & 1 & 3.20 & 1 & 3.30 & & & & \\
\hline \multicolumn{11}{|l|}{ Type of stroke } \\
\hline Ischemic & 49 & 80.30 & 27 & 87.10 & 22 & 73.30 & 3.09 & 2 & .213 & .22 \\
\hline Haemorrhagic & 12 & 19.70 & 4 & 12.90 & 8 & 26.70 & & & & \\
\hline \multicolumn{11}{|l|}{ Age } \\
\hline Mean age & 64 & & 63 & & 65 & & & & .989 & \\
\hline Age range & $44-84$ & & $47-84$ & & $44-84$ & & & & & \\
\hline
\end{tabular}

Table 2

Mean results of the studied groups in SF-36 depending on the time of measurement

\begin{tabular}{|c|c|c|c|c|c|c|c|c|}
\hline & \multicolumn{4}{|c|}{ Pre-test } & \multicolumn{4}{|c|}{ Post-test } \\
\hline & \multicolumn{2}{|c|}{$\begin{array}{l}\text { Control group } \\
\quad(n=31)\end{array}$} & \multicolumn{2}{|c|}{$\begin{array}{c}\text { Intervention } \\
\text { group } \\
(n=30)\end{array}$} & \multicolumn{2}{|c|}{$\begin{array}{l}\text { Control group } \\
\quad(n=31)\end{array}$} & \multicolumn{2}{|c|}{$\begin{array}{c}\text { Intervention } \\
\text { group } \\
(n=30)\end{array}$} \\
\hline & $M$ & $S D$ & $M$ & $S D$ & $M$ & $S D$ & $M$ & $S D$ \\
\hline Physical functioning & 13.19 & 4.22 & 12.93 & 3.01 & 16.00 & 5.38 & 17.43 & 4.73 \\
\hline Physical limitations & 4.32 & 0.83 & 4.23 & 0.50 & 4.71 & 0.94 & 5.00 & 1.05 \\
\hline Bodily pain & 7.23 & 2.91 & 8.53 & 2.10 & 8.16 & 2.67 & 8.63 & 2.31 \\
\hline General health perceptions & 15.32 & 3.44 & 14.33 & 3.69 & 15.97 & 3.70 & 17.43 & 3.10 \\
\hline Vitality & 12.61 & 4.29 & 14.03 & 3.83 & 14.52 & 3.84 & 18.63 & 3.19 \\
\hline Social functioning & 5.97 & 2.86 & 5.73 & 2.27 & 6.81 & 2.47 & 7.37 & 1.87 \\
\hline Emotional limitations & 4.52 & 1.36 & 5.03 & 1.27 & 5.00 & 1.29 & 5.83 & 0.53 \\
\hline Mental health & 18.23 & 6.68 & 20.03 & 5.33 & 20.48 & 5.81 & 24.23 & 3.67 \\
\hline
\end{tabular}

Results of the analysis of HRQL measured with the SF-36 questionnaire are presented in Table 2 and Table 3.

In both groups a significant improvement of quality of life in the second measurement was observed. This effect was significant for the following subscales: physical functioning $(F(1,59)=74.76$, $\left.p<.001, \eta^{2}=.56\right)$, physical limitations $(F(1,59)=28.03$, $\left.p<.001, \eta^{2}=.32\right)$, general health perceptions $\left(F(1,59)=38.97, p<.001, \eta^{2}=.40\right)$, vitality
$\left(F(1,59)=72.89, p<.001, \eta^{2}=.55\right)$, social functioning $\left(F(1,59)=30.01, p<.001, \eta^{2}=.34\right)$, emotional limitations $\left(F(1,59)=24.49, p<.001, \eta^{2}=.29\right)$, mental health $\left(F(1,59)=49.97, p<.001, \eta^{2}=.46\right)$. It was weak only in terms of perceived pain (borderline significant: $\left.F(1,59)=3.76, p=.057, \eta^{2}=.06\right)$.

The improvement of quality of life was stronger in the IG: for the following aspects: physical functioning $\left(F(1,59)=4.02, p=.050, \eta^{2}=.06\right)$, general health $(F(1$, $\left.59)=16.74, p<.001, \eta^{2}=.22\right)$, vitality $(F(1,59)=12.53$, 
Table 3

Effectiveness of music therapy in changing the HRQL assessment measured with the SF-36 questionnaire

\begin{tabular}{lccccccccc}
\hline \multirow{2}{*}{ Measure } & \multicolumn{3}{c}{ Group } & \multicolumn{3}{c}{ Measurement } & \multicolumn{3}{c}{ Group*Measurement } \\
\cline { 2 - 10 } & $F(1,59)$ & \multicolumn{1}{c}{$p$} & $\eta^{2}$ & $F(1,59)$ & $p$ & $\eta^{2}$ & $F(1,59)$ & $p$ & $\eta^{2}$ \\
\hline Physical functioning & 0.31 & .579 & .01 & 74.76 & $<.001$ & .56 & 4.02 & .050 & .06 \\
Physical limitations & 0.28 & .599 & .01 & 28.03 & $<.001$ & .32 & 3.03 & .087 & .05 \\
Bodily pain & 2.29 & .135 & .04 & 3.76 & .057 & .06 & 2.45 & .123 & .04 \\
General health perceptions & 0.08 & .778 & .00 & 38.97 & $<.001$ & .40 & 16.74 & $<.001$ & .22 \\
Vitality & 9.50 & .003 & .14 & 72.89 & $<.001$ & .55 & 12.53 & .001 & .18 \\
Social functioning & 0.08 & .777 & .00 & 30.01 & $<.001$ & .34 & 3.10 & .083 & .05 \\
Emotional limitations & 6.28 & .015 & .10 & 24.49 & $<.001$ & .29 & 1.49 & .228 & .03 \\
Mental health & 4.35 & .041 & .07 & 49.97 & $<.001$ & .46 & 4.52 & .038 & .07 \\
\hline
\end{tabular}

Music therapy after a stroke $\left.p<.001, \eta^{2}=.18\right)$ and mental health $((F(1,59)=4.52$, $\left.\left.p=.038, \eta^{2}=.07\right)\right)$, and near statistical significance: role limitations due to physical health $(F(1,59)=3.03$, $\left.p=.087, \eta^{2}=.05\right)$ and social functioning $\left(F(1,59)=3.10, p=.083, \eta^{2}=.05\right)$. Only in terms of role limitations due to emotional health $\left(F(1,59)=1.49, p=.228, \eta^{2}=.03\right)$ and pain $(F(1,59)=2.45$, $\left.p=.123, \eta^{2}=.04\right)$ was participation in MT not associated with a significant change in levels of functioning.

Similarly, the analysis of results for HRQL measured by the SA-SIP30 questionnaire (Table 4 and Table 5) revealed an increase in HRQL in the second measurement in both groups of subjects. Here it was possible to observe a significant change favouring MT in HRQL in specific aspects such as communication $\left(F(1,59)=4.11, p=.047, \eta^{2}=.07\right)$ emotional condition $\left(F(1,59)=16.07, p<.001, \eta^{2}=.21\right)$ and alertness behaviour $\left(F(1,59)=7.62, p=.008, \eta^{2}=.11\right)$, which was also expressed in the overall score $\left(F(1,59)=8.16, p=.006, \eta^{2}=.12\right)$. No significant changes were revealed with regards to dimensions such as body care and movement $(F(1,59)=1.27$, $\left.p=.264, \eta^{2}=.02\right)$, social interaction $(F(1,59)=1.12$, $\left.p=.295, \eta^{2}=.02\right)$, mobility $(F(1,59)=0.02, p=.897$, $\left.\eta^{2}=.00\right)$, household management $(F(1,59)=0.10$, $\left.p=.752, \eta^{2}=.00\right)$, and ambulation $(F(1,59)=2.60$, $\left.p=.112, \eta^{2}=.04\right)$

Results from the Cantril Ladder are illustrated in Table 6 and Table 7. Taking part in MT fostered an improvement in quality of life manifested in an improved assessment of one's current quality of life $\left.F(1,59)=15.41, p<.001, \eta^{2}=.21\right)$ and the quality of life expected in one's future $(F(1,59)=7.61, p=.008$, $\eta^{2}=.11$, while it does not influence the assessment of

Table 4

Mean results of the studied groups in SA-SIP30 depending on the time of measurement

\begin{tabular}{|c|c|c|c|c|c|c|c|c|}
\hline & \multicolumn{4}{|c|}{ Pre-test } & \multicolumn{4}{|c|}{ Post-test } \\
\hline & \multicolumn{2}{|c|}{$\begin{array}{l}\text { Control group } \\
\quad(n=31)\end{array}$} & \multicolumn{2}{|c|}{$\begin{array}{c}\text { Intervention } \\
\text { group } \\
(n=30) \\
\end{array}$} & \multicolumn{2}{|c|}{$\begin{array}{l}\text { Control group } \\
\quad(n=31)\end{array}$} & \multicolumn{2}{|c|}{$\begin{array}{c}\text { Intervention } \\
\text { group } \\
(n=30)\end{array}$} \\
\hline & $M$ & $S D$ & $M$ & $S D$ & $M$ & $S D$ & $M$ & $S D$ \\
\hline Body care and movement & 4.26 & 1.24 & 4.27 & 1.05 & 3.68 & 1.54 & 3.37 & 1.59 \\
\hline Social interaction & 1.74 & 1.46 & 1.90 & 1.21 & 1.10 & 1.17 & 0.97 & 0.96 \\
\hline Mobility & 2.87 & 0.34 & 2.80 & 0.61 & 2.55 & 0.81 & 2.50 & 0.78 \\
\hline Communication & 0.94 & 0.89 & 1.40 & 1.13 & 0.71 & 0.78 & 0.80 & 0.93 \\
\hline Emotional condition & 1.35 & 1.28 & 1.57 & 1.31 & 1.16 & 1.16 & 0.40 & 0.68 \\
\hline Household management & 3.94 & 0.25 & 3.90 & 0.31 & 3.35 & 1.11 & 3.23 & 1.17 \\
\hline Alertness behaviour & 1.52 & 1.18 & 1.97 & 1.07 & 1.10 & 1.01 & 0.93 & 1.02 \\
\hline Ambulance & 2.87 & 0.34 & 3.00 & 0.00 & 2.77 & 0.43 & 2.67 & 0.76 \\
\hline Total & 19.48 & 4.24 & 20.80 & 4.26 & 16.42 & 4.63 & 14.90 & 4.62 \\
\hline
\end{tabular}


Table 5

Effectiveness of music therapy in changing the assessment of HRQL measured by the SA-SIP30 questionnaire

Ilona PoćwierzMarciniak, Mariola Bidzan

\begin{tabular}{lccccccccc}
\hline \multirow{2}{*}{ Measure } & \multicolumn{3}{c}{ Group } & \multicolumn{4}{c}{ Measurement } & \multicolumn{3}{c}{ Group*Measurement } \\
\cline { 2 - 10 } & $F(1,59)$ & \multicolumn{1}{c}{$p$} & $\eta^{2}$ & $F(1,59)$ & $p$ & $\eta^{2}$ & $F(1,59)$ & $p$ & $\eta^{2}$ \\
\hline Body care and movement & 0.22 & .640 & .00 & 27.30 & $<.001$ & .32 & 1.27 & .264 & .02 \\
Social interaction & 0.00 & .960 & .00 & 33.47 & $<.001$ & .36 & 1.12 & .295 & .02 \\
Mobility & 0.17 & .683 & .00 & 12.88 & .001 & .18 & 0.02 & .897 & .00 \\
Communication & 1.56 & .217 & .03 & 20.03 & $<.001$ & .25 & 4.11 & .047 & .07 \\
Emotional condition & 1.08 & .302 & .02 & 31.40 & $<.001$ & .35 & 16.07 & $<.001$ & .21 \\
Household management & 0.23 & .632 & .00 & 21.14 & $<.001$ & .26 & 0.10 & .752 & .00 \\
Alertness behaviour & 0.33 & .569 & .01 & 42.64 & $<.001$ & .42 & 7.62 & .008 & .11 \\
Ambulance & 0.01 & .909 & .00 & 8.59 & .005 & .13 & 2.60 & .112 & .04 \\
Total & 0.01 & .921 & .00 & 81.54 & $<.001$ & .58 & 8.16 & .006 & .12 \\
\hline
\end{tabular}

Table 6

Mean results of the studied groups in Cantril Ladder depending on the time of measurement

\begin{tabular}{|c|c|c|c|c|c|c|c|c|}
\hline & \multicolumn{4}{|c|}{ Pre-test } & \multicolumn{4}{|c|}{ Post-test } \\
\hline & \multicolumn{2}{|c|}{$\begin{array}{l}\text { Control group } \\
\quad(n=31)\end{array}$} & \multicolumn{2}{|c|}{$\begin{array}{l}\text { Intervention } \\
\text { group } \\
(n=30)\end{array}$} & \multicolumn{2}{|c|}{$\begin{array}{l}\text { Control group } \\
\quad(n=31)\end{array}$} & \multicolumn{2}{|c|}{$\begin{array}{c}\text { Intervention } \\
\text { group } \\
(n=30)\end{array}$} \\
\hline & $M$ & $S D$ & $M$ & $S D$ & $M$ & $S D$ & $M$ & $S D$ \\
\hline Quality of life before illness & 7.65 & 2.23 & 8.13 & 1.98 & 7.65 & 2.30 & 8.37 & 2.30 \\
\hline Current quality of life & 4.19 & 2.47 & 4.20 & 2.38 & 5.26 & 2.45 & 7.53 & 1.55 \\
\hline Quality of life in 3 years & 7.77 & 2.40 & 8.13 & 2.26 & 7.68 & 2.36 & 9.23 & 1.22 \\
\hline
\end{tabular}

Table 7

Effectiveness of music therapy in changing the assessment of HRQL measured with the Cantril Ladder

\begin{tabular}{lcccccccccc}
\hline \multirow{2}{*}{ Measure } & \multicolumn{3}{c}{ Group } & \multicolumn{4}{c}{ Measurement } & \multicolumn{3}{c}{ Group*Measurement } \\
\cline { 2 - 11 } & $F(1,59)$ & \multicolumn{1}{c}{$p$} & $\eta^{2}$ & $F(1,59)$ & $p$ & $\eta^{2}$ & $F(1,59)$ & $p$ & $\eta^{2}$ \\
\hline Quality of life before illness & 1.23 & .272 & .02 & 0.63 & .429 & .01 & 0.63 & .429 & .01 \\
Current quality of life & 5.24 & .026 & .08 & 57.89 & $<.001$ & .50 & 15.41 & $<.001$ & .21 \\
Quality of life in 3 years & 3.70 & .059 & .06 & 5.34 & .024 & .08 & 7.61 & .008 & .11 \\
\hline
\end{tabular}

quality of life from before the stroke - the interaction effect is insignificant here $(F(1,59)=0.63, p=.429$, $\left.\eta^{2}=.01\right)$.

\section{DISCUSSION}

The aim of the current study was to assess the efficacy of MT in improving HRQL in individuals who experienced stroke and are undergoing rehabilitation.

Our results confirm that participation in MT is associated with greater improvement in HRQL compared to the CG. The biggest changes were observed in subscales concerned with mental functioning, such as emotional state, ability to focus one's attention, as well as communication, and to a lesser degree in those concerned with physical functioning. Taking part in MT did not have an impact on the improvement of quality of life in the spheres of pain, body care and movement, mobility, limitations in role fulfilment due to emotional reasons and the assessment of quality of life before the stroke. It is probably associated with the fact that the main goal of the administered MT programme was to improve mental functioning, and it was not created with motor function improvement in mind. Hence, in the majority of the subscales that were concerned with motor functioning, no between-group differences were observed. 
We conclude that the quality of life was improved due to an improvement of selected aspects of mental functioning.

Despite the fact that the literature does not provide evidence for the improvement of quality of life due to the influence of MT in post-stroke individuals, there are a few studies confirming the positive impact of MT on selected aspects of mental functioning in this group of patients. As in the current study, research by Purdie et al. (1997) the improvement of communication skills and psychological condition of patients taking part in MT were on the threshold of statistical significance. A similar result was observed in the realm of mood in the study by Nayak et al. (2000), which is in line with our results, though we did not measure mood directly, but rather emotional state - which is one of the HRQL subscales. Research by Jeong and Kim (2007) also showed a significant improvement in mood and interpersonal relations. Results on selected subscales used in our study are in line with the results of Särkämö et al. (2008), who observed an improvement with regards to higher levels of attention focusing, lower levels of depression, and lower levels of decreased mood in a group listening to music, in comparison to a group listening to audiobooks, as well as a control group. This fact is also confirmed by results obtained by Forsblom et al. (2010). Here, again, the group listening to music scored better with regards to mood, relaxation, and motor activity. As in our study, the psychological state of post-stroke patients improved under the influence of MT in research by Kim et al. (2011), as well as Chen et al. (2013), where levels of depression and anxiety decreased in MT participants. The active approach of MT positively influenced mood in research by Van Vugt et al. (2014) and Jun et al. (2012). However, one ought to remember that in our study MT was mainly based on a receptive approach.

A great majority of the discussed research used group MT, which gives the opportunity to form interpersonal relations and practise social skills. Hence, in some studies an increase of such skills was observed (Purdie et al., 1997; Nayak et al., 2000; Jeong \& Kim, 2007). The current study used one-on-one MT, which does not provide the opportunity to form relations in a group, though the topic of relations with those close to the patient was discussed (the "Around interpersonal relations" meetings cycle). This may be why the quality of life in the aspect of social functioning measured by SF-36 in people taking part in MT showed an increase, but only on the border of significance.

Despite the fact that the implemented MT programme was focused on the physical sphere, a greater improvement in the quality of life in aspects of physical functioning was observed in the MT group, because another MT programme was used, which aims to rhythmically stimulate motor functions (Thaut, 1999; Paul \& Ramsey, 2000; Hurt \& Thaut,
2009; Bukowska, 2012; Bradt et al., 2010). It may be that in the current study the breathing exercises with music were of importance; however, it is more probable that the IG was simply more optimistic in the assessment of their overall functioning than the CG. This would be in line with the fact that individuals who took part in MT assessed not only their current quality of life as higher but also their expected quality of life in the future, at the end of the therapy programme. And as shown by Katona's team (Katona et al., 2015), the higher the HRQL in stroke patients directly after release from hospital was, the higher were its levels one and 2.50 years later.

It is worth stressing that our results confirm the fact that in individuals who have experienced a stroke, the quality of life improves with time elapsed since stroke and the undertaken rehabilitation of motor functions (independent of taking part in MT, though as described before, taking part in MT additionally increased the improvement of HRQL) (Carod-Artal et al., 2000; Hopman \& Verner, 2003; Tramonti, Fanciullacci, Giunti, Rossi, \& Chisari, 2014; Rasmussen et al., 2016). However, it was possible to see some differences in terms of particular dimensions of HRQL in our study in comparison to other studies. For instance, in Canadian research by Hopman and Verner (2003) no significant improvement of quality of life was observed in the areas of limitations due to either physical and emotional reasons or vitality, but an increase of HRQL in the pain subscale was observed. In comparison, in the current study there was an increase in those three aspects, and no increase in the score for pain. In turn, our results on the pain subscale are in line with the results of an Italian study by Tramonti's team (Tramonti et al., 2014), in which the quality of life measured by SF-36 decreased only in the aspect of pain, while in all other dimensions an improvement was observed. Moreover, subscales such as physical functioning, limitations in fulfilling roles due to physical and emotional reasons, as well as mental health correlated with physical ability and the associated independence. Undoubtedly, the gradual improvement of physical functioning translates into an improvement in quality of life, while the presence of pain lowers the quality of life. Differences between observations regarding the pain subscale in different studies may be due to different levels of pain treatment in different countries, as well as cultural differences with regards to, for example, openness towards admitting such problems.

Our research has shown that MT has a positive influence on HRQL of post-stroke individuals in a Polish cohort, which is a new contribution to the research on the role of MT in neurological rehabilitation.

However, it is important to underline that the current study on the influence of MT on HRQL in individuals affected with stroke has some limitations, because other uncontrolled-for factors could have in-
Music therapy after a stroke 
Ilona PoćwierzMarciniak, Mariola Bidzan fluenced the quality of life of participants (e.g. family factors, support received, events that take place in the patients' everyday functioning while hospitalised) which could interfere with the reliability of the results. It is also worth asking whether another therapeutic method would not be equally as effective. While research by Särkämö et al. (2008) and Forsblom et al. (2010) suggests that listening to literature is not as effective in mood alleviation as is MT, there are no studies that compare MT with other forms of therapy aimed at improving quality of life in stroke patients. It is also worth emphasizing that in both studied groups the quality of life has improved, and only in selected aspects did a greater increase occur in the MT group.

\section{CONCLUSIONS}

The results suggest that using MT during neurological rehabilitation in stroke patients is effective in increasing the assessment of selected aspects of HRQL, especially those associated with psychological functioning. This is a rationale for implementing this form of therapy as a regular treatment in the neurorehabilitation of individuals who have experienced a stroke. In future research it would be worthwhile to widen the scope of the study to include more subjects, and also perform a follow-up measurement, e.g. a year later, to make inferences about long-term effects of MT. Moreover, more research is needed to explore the differential impact of various MT approaches, frequencies, durations, and interventional time points.

\section{References}

Aldridge, D., Gustorff, D., \& Hannich, H. J. (1990). Where I am? Music therapy applied to coma patients. Journal of the Royal Society of Medicine, 83, 345-346.

Ayis, S., Wellwood, I., Rudd, A. G., McKevitt, C., Parkin, D., \& Wolfe, C. D. (2015). Variations in Health-Related Quality of Life (HRQoL) and survival 1 year after stroke: five European population-based registers. BMJ Open, 5, e007101.

Baker, F., \& Tamplin, J. (2006). Music Therapy Methods in Neurorehabilitation. A Clinician's Manual. London and Philadelphia: Jessica Kingsley Publishers.

Bonde, L. O. (2004). The Bonny Method of Guided Imagery and Music with cancer survivors. A psychosocial study with focus on the influence of BMGIM on mood and quality of life. Aalborg: Aalborg University.

Bonny, H. L. (2002). Music Consciousness: The evolution of Guided Imagery and Music. Barcelona: Gilsum.
Bozuk, H., Artac, M., Kara, A., Ozdogan, M., \& Sulp, Y. (2006). Does music exposure during chemotherapy improve quality of life in early breast cancer? Medical Science Monitor, 12, 200-205.

Bradt, J., \& Dileo, C. (2009). Music for stress and anxiety reduction in coronary heart disease patients. Cochrane Database of Systematic Review, 2, CD006577.

Bradt, J., Magee, W. L., \& Dileo, C. (2010). Music interventions for acquired brain injury. Cochrane Database of Systematic Review, 7, CD006787.

Bukowska, A. (2012). Muzykoterapia neurologiczna [Neurological music therapy]. In K. Stachyra (ed.), Modele, metody i podejścia w muzykoterapii [Models, methods and approaches in music therapy] (pp. 165-178). Lublin: Wydawnictwo Uniwersytetu Marii Curie-Skłodowskiej.

Burns, D. S. (2001). The effect of the Bonny Method of Guided Imagery and Music on the mood and life quality of cancer patients. Journal of Music Therapy, 38, 51-65.

Cantril, H. (1965). The patterns of human concerns. New Brunswick: Rutgers University Press.

Carod-Artal, J., Egido, J. A., Gonzales, J. L., \& de Seijas, E. V. (2000). Quality of life among stroke survivors evaluated 1 year after stroke. Stroke, 31, 2995-3000.

Carod-Artal, J., Trizotto, S. D., Ferreira Coral, L., \& Menezes Moreira, C. (2009). Determinants of quality of life in Brazilian stroke survivors. Journal of the Neurological Sciences, 284, 63-68.

Chen, M. C., Tsai, P. L., Huang, Y. T., \& Lin, K. C. (2013). Pleasant music improves visual attention in patients with unilateral neglect after stroke. Brain Injuries, 27, 75-82.

Chen, L. M., Ran, M. D., Liu, B. Q., Zhao, J., \& Zhu, C. R. (2015a). Changes on health-related quality of life in incipient stroke survivors. Journal of Sichuan University, 46, 243-247.

Chen, C. M., Tsai, C., Chung, C.Y., Chen, C. L., Wu, K., \& Chen, H. C. (2015b). Potential predictors for health-related quality of life in stroke patients undergoing inpatient rehabilitation. Health and Quality of Life Outcomes, 13, 118-128.

Chou, C. Y. (2015). Determinants of the health-related quality of life for stroke survivors. Journal of Stroke and Cerebrovascular Diseases, 24, 655-662.

Cohen, N., \& Masse, R. (1993). The application of singing and rhythmic instruction as a therapeutic intervention for persons with neurogenic communication disorders. Journal of Music Therapy, 30, 81-89.

Cumming, T. B., Brodtmann, A., Darby, D., \& Bernhardt, J. (2014). The importance of cognition to quality of life after stroke. Journal of Psychosomatic Research, 77, 374-379.

de Dreu, M. J., van der Wilk, A. S., Poppe, E., Kwakkel, G., \& van Wegen, E. E. (2012). Rehabilitation, 
exercise therapy and music in patients with Parkinson's diseases: a meta-analysis of the effects of music-based-movement therapy on walking ability, balance and quality of life. Parkinsonism \& Related Disorders, 18, 114-119.

Doğan, M. V., \& Şenturan, L. (2012). The effect of music therapy on the level of anxiety in the patients undergoing coronary angiography. Open Journal of Nursing, 2, 165-169.

Dubois, B., Slachevsky, A., Litvan, I., \& Pillon, B. (2000). The FAB: a Frontal Assessment Battery at bedside. Neurology, 55, 1621-1626.

Folstein, M. F., Folstein, S. E., \& McHugh, P. R. (1975). "Mini-mental state": a practical method for grading the cognitive state of patients for the clinician. Journal of Psychiatry Research, 12, 189-198.

Forsblom,A.,Särkämö,T., Laitinen, S., \& Tervaniemi, M. (2010). The effect of music and audiobook listening on people recovering from stroke: The patient's point of view. Music and Medicine, 2, 229-233.

Gamrowska, A., \& Steuden, S. (2014). Coping with the events of daily life and quality of life of the socially active elderly. Health Psychology Report, 2, 123-131.

Gilbertson, S. (2005). Music therapy in neurorehabilitation after traumatic brain injury: a literature review. In D. Aldridge (ed.), Music Therapy and Neurological Rehabilitation: Performing Health (pp. 83-137). London: Jessica Kingsley Publishers.

Guajardo, V. D., Terroni, L., Sobreiro, M. F., Zerbini, M. I., Tinone, G., Scaff, M., Iosifescu, D. V., de Lucia, M. C., \& Fraguas, R. (2015). The influence of depressive symptoms on quality of life after stroke: a prospective study. Journal of Stroke and Cerebrovascular Diseases, 24, 201-209.

Haghgoo, H. A., Pazuki, E. S., Hosseini, A. S., \& Rassafiani, M. (2013). Depression, activities of daily living and quality of life in patients with stroke. Journal of the Neurological Sciences, 328, 87-91.

Hopman, W. M., \& Verner, J. (2003). Quality of life during and after inpatient stroke rehabilitation. Stroke, 34, 801-805.

Hurt, C., \& Thaut, C. (2009). Clinical practice in music therapy. In S. Hallam, I. Cross, \& M. Thaut (eds.), Music Psychology (pp. 503-514). Oxford: Oxford University Press.

Jaracz, K., \& Kozubski, W. (2006). Jakość życia chorych po udarze mózgu w świetle badań empirycznych [Quality of life of stroke patients in light of empirical studies]. Aktualności Neurologiczne, 2, 34-45.

Jeong, S., \& Kim, M. T. (2007). Effects of a theory-driven music and movement program for stroke survivors in a community setting. Applied Nursing Research, 20, 125-131.

Joske, D. J. L., Rao, A., \& Kristjanson, L. (2006). Critical review of complementary therapies in haemato-oncology. Internal Medicine Journal, 36, 579-586.
Jun, E. M., Roh, Y. H., \& Kim, M. J. (2012). The effect of music-movement therapy on physical and psychological states of stroke patients. Journal of Clinical Nursing, 22, 22-31.

Kamioka, H., Tsutani, K., Yamada, M., Park, H., Okuizumi, H., Tsuruoka, K., Honda, T., Okada, S., Park, S., Kitayuguchi, J., Abe, T., Handa, S., Oshio, T., \& Mutoh, Y. (2014). Effectiveness of music therapy: a summary of systematic reviews based on randomized controlled trials of music interventions. Patient Preference and Adherence, 8, 727-754.

Katona, M., Schmidt, R., Schupp, W., \& Graessel, E. (2015). Predictors of health-related quality of life in stroke patients after neurological inpatient rehabilitation: a prospective study. Health and Quality of Life Outcomes, 13, 58-65.

Kennelly, J., \& Brien-Elliot, K. (2001). The role of music therapy in paediatric rehabilitation. Paediatric Rehabilitation, 4, 137-143.

Kiebert, G. M. (1997). Jakość życia jako rezultat badań klinicznych w onkologii [Quality of life as a result of clinical studies in oncology]. In J. Meyza (ed.), Jakość życia w chorobie nowotworowej. Wybrane zagadnienia [Quality of life in illness. Selected problems] (pp. 43-57). Warszawa: Centrum Onkologii Instytutu im. Marii Skłodowskiej-Curie. Kim, D. S., Park, Y. G., Choi, J. H., Im, S. H., Jung, K. J., Cha, Y. A., Jung, C. O., \& Yoon, Y. H. (2011). Effects of music therapy on mood in stroke patients. Yonsei Medical Journal, 52, 977-981.

Kwok, T., Lo, R. S., Wong, E., Wai-Kwong, T., Mok, V., \& Kai-Sing, W. (2006). Quality of life of stroke survivors: a 1-year follow-up study. Archives of Physical Medicine and Rehabilitation, 87, 1177-1182.

McKinney, C. (1990). The effect of music on imagery. Journal of Music Therapy, 20, 34-46.

Metera, A. (2002). Muzykoterapia. Muzyka w medycynie i edukacji [Music therapy. Music in medicine and education]. Leszno: Wydawnictwo Centrum Technik Nauki Metronom.

Mielnik, M., \& Mielnik-Matityahu, J. (2013). The effects of skills acquired during musical training on brain functions and the course of neurorehabilitation. Acta Neuropsychologica, 11, 47-51.

Min, K. B., \& Min, J. Y. (2015). Health-related quality of life is associated with stroke deficits in older adults. Age and Aging, 44, 700-704.

Nayak, S., Wheeler, B. L., Shiflett, S. C., \& Agostinelli, S. (2000). Effect of music therapy on mood and social interaction among individuals with acute traumatic brain injury and stroke. Rehabilitation Psychology, 45, 274-283.

Nowak, M., Bidzan, I., Śniegowski, K., \& Cieśla, P. (2014). Dolegliwości ortopedyczne w przerzutowym raku płuca - opis przypadku. Specyfika podejścia [Orthopaedic afflictions in metastatic lung cancer - a case study. Specifics of the approach]. Psychoonkologia, 2, 73-81.
Music therapy after a stroke 
Oros, R. I., Popescu, C. A., lova, S. O., Mihancea, P., \& lova, C. A. (2016). Depression, activities of daily living and quality of life in elderly stroke patients. Human and Veterinary Medicine, 8, 24-28.

Owolabi, M. O. (2013). Consistent determinants of post-stroke health-related quality of life across diverse cultures: Berlin-Ibadan study. Acta Neurologica Scandinavica, 128, 311-320.

Paul, S., \& Ramsey, D. (2000). Music therapy in physical medicine and rehabilitation. Australian Occupational Therapy Journal, 47, 111-118.

Ilona PoćwierzMarciniak, Mariola Bidzan a stopniowa utrata sprawności ruchowej. Aspek-
Poćwierz-Marciniak, I., \& Bidzan, M. (2015). Nagta ty psychospoteczne [Sudden vs. gradual loss of physical ability. Psychosocial aspects]. In M. Bidzan \& Ł. Bieleninik (eds.), Niepetnosprawność ruchowa w ujęciu biopsychospotecznym. Wyzwania diagnozy, rehabilitacji i terapii [Motor disability in a biopsychosocial perspective. Challenges in diagnosing, rehabilitation and therapy] (pp. 67-99). Gdańsk: Wydawnictwo Harmonia Universalis.

Poćwierz-Marciniak, I. (2014). Music therapy in the rehabilitation of a stroke patient. Acta Neuropsychologica, 12, 85-102.

Purdie, H., Hamilton, S., \& Baldwin, S. (1997). Music therapy: facilitating behavioural and psychological change in people with stroke - a pilot study. International Journal of Rehabilitation Research, 20, 325-327.

Rasmussen, R. S., Østergaard, A., Kjaer, P., Skerris, A., Skou, C., Chrisoffersen, J., Seest, L. S., Poulsen, M. B., Ronholt, F., \& Overgaard, K. (2016). Stroke rehabilitation at home before and after discharge reduced disability and improved quality of life: a randomized controlled trial. Clinical Rehabilitation, 30, 225-236.

Ruud, E. (1997). Music and the Quality of Life. Nordic Journal of Music Therapy, 6, 86-97.

Sand, K. M., Naess, H., Midelfart, A., Thomassen, L., \& Hoff, J. M. (2016). Vision problems in ischaemic stroke patients: effects on life quality and disability. European Journal of Neurology, 23, 1-7.

Särkämö, T., Tervaniemi, M., Laitinen, S., Forsblom, A., Soinila, S., Mikkonen, M., Autti, T., Silvennoinen, H. M., Erkkilä, J., Laine, M., Peretz, I., \& Hietanen, M. (2008). Music listening enhances cognitive recovery and mood after middle cerebral artery stroke. Brain, 131, 866-876.

Schipper, H. (1990). Quality of Life: Principles of the Clinical Paradigm. Journal of Psychosocial Oncology, 8, 171-185.

Schou, K. (2014). Music therapy for stress and anxiety reduction in patients with coronary heart disease. Journal Medical Music Therapy, 7, 1-13.

Sena-Moore, K. (2013). A systematic review on the neural effects of music on emotion regulation: implications for music therapy practice. Journal of Music Therapy, 50, 198-242.
Sheldenkar, A., Crichton, S., Douiri, A., Rudd, A. G., Wolfe, C. D., \& Chen, R. (2014). Temporal trends in health-related quality of life after stroke: analysis from the South London Stroke Register 19952011. International Journal of Stroke, 9, 721-727.

Shi, Y. Z., Xiang, Y. T., Yang, Y., Zhang, N., Wang, S., Ungvari, G., Chiu, H., Tang, W. K., Wang, Y. L., Zhao, X. Q., Wang, Y. J., \& Wang, C. X. (2016). Depression after minor stroke: the association with disability and quality of life - a 1-year follow-up study. International Journal of Geriatric Psychiatry, 31, 421-427.

Stachyra, K. (ed.). (2012). Modele, metody i podejścia w muzykoterapii [Models, methods and approaches in music therapy]. Lublin: Wydawnictwo Uniwersytetu Marii Curie-Skłodowskiej.

Stańczyk, M. (2010). Wpływ muzykoterapii na jakość życia pacjentów onkologicznych objętych opieką paliatywną [The influence of music therapy on quality of life of oncology patients in palliative care]. In W. Szulc (ed.), Arteterapia jako dyscyplina akademicka w krajach europejskich [Art therapy as an academic discipline in European countries] (pp. 177-181). Wrocław: Atut.

Stańczyk, M. (2012). Muzykoterapia w procesie kompleksowego leczenia pacjentów onkologicznych [Music therapy in the process of comprehensive treatment of oncology patients]. Hygeia Public Health, 47, 424-426.

Szczudlik, A., Członkowska, A., Kwieciński, H., \& Słowik, A. (eds.). (2007). Udar mózgu [Stroke]. Kraków: Wydawnictwo Uniwersytetu Jagiellońskiego.

Szulc, W. (2011). Arteterapia. Narodziny idei, ewolucja teorii, rozwój praktyki [Art therapy. The birth of the idea, evolution of the theory and development of practise]. Warszawa: Difin.

Tamplin, J. (2000). Improvisational music therapy approaches to coma arousal. Australian Journal of Music Therapy, 11, 38-51.

Tamplin, J. (2005). The effects of vocal exercises and singing on the speech of people with acquired dysarthria. Melbourne: University of Melbourne.

Thaut, M. H. (1989). The influence of music therapy interventions on self-rated changes in relaxation, affect, and thought in psychiatric prisoner-patients. Journal of Music Therapy, 26, 155-166.

Thaut, M. (1999). Training Manual for Neurologic Music Therapy. Fort Collins, CO: Centre for Biomedical Research in Music, Colorado State University.

Thaut, M. (2005). Rhythm, music and the brain. Scientific foundations and clinical applications. New York and London: Routledge.

Tong, Y., Forreider, B., Sun, X., Geng, X., Zhang, W., Du, H., Zhang, T., \& Ding, Y. (2015). Music-supported therapy (MST) in improving post-stroke patients' upper-limb motor function: a randomized controlled pilot study. Neurological Research, 37, 434-440. 
Tramonti, F., Fanciullacci, C., Giunti, G., Rossi, B., \& Chisari, C. (2014). Functional status and quality of life of stroke survivors undergoing rehabilitation programmes in a hospital setting. NeuroRehabilitation, 35, 1-7.

Turaj, W. (2007). Objawy i zespoły kliniczne udaru [Symptoms and clinical syndromes of stroke]. In A. Szczudlik, A. Członkowska, H. Kwieciński, \& A. Słowik (eds.), Udar mózgu (pp. 189-193). Kraków: Wydawnictwo Uniwersytetu Jagiellońskiego.

Tylka, J., \& Piotrowicz, R. (2009). Kwestionariusz oce-

Music therapy ny jakości życia SF-36 - wersja polska. Kardiologia Polska, 67, 1166-1169.

Van Mierlo, M. L., Schroeder, C., Van Heughten, C. M., Post, M., de Kort, P., \& Visser-Meily, J. (2014). The influence of psychological factors on Health-Related Quality of Life after stroke: a systematic review. International Journal of Stroke, 9, 341-348.

Van Mierlo, M. L., Van Heughten, C. M., Post, M., Hajos, T., Kapelle, L. J., \& Visser-Meily, J. (2016). Quality of life during the two years post stroke: the restore stroke cohort study. Cerebrovascular Diseases, 41, 19-26.

Van Straten, A., de Hahn, R. J., \& Limburg, M. (1997). A stroke-adapted 30-item version of the Sickness Impact Profile to assess quality of life (S.A.-SIP 30). Stroke, 28, 2155-2161.

Van Vugt, F. T., Ritter, J., Rollnik, J. D., \& Altenmüller, E. (2014). Music-supported motor training after stroke reveals no superiority of synchronization in group therapy. Frontiers in Human Neuroscience, 8, 315.

Vink, A. C., Bruinsma, M. S., \& Scholten, R. (2013). Music therapy for people with dementia (Review). The Cochrane Collaboration: John Wiley \& Sons.

Visser, M., Heijenbrok-Kal, M., Spijker, A., Oostra, K., Busschbach, J., \& Ribbers, G. (2015). Coping, problem solving, depression, and health-related quality of life in patients receiving outpatient stroke rehabilitation. Archives of Physical Medicine and Rehabilitation, 96, 1492-1498.

Walden-Gałuszko, K. de (1997). Ocena jakości życia uwarunkowana stanem zdrowia [Assessment of quality of life determined by health condition]. In J. Meyza (ed.), Jakość życia w chorobie nowotworowej. Wybrane zagadnienia [Quality of life in cancer. Selected issues] (pp. 77-84). Warszawa: Centrum Onkologii Instytutu im. Marii Skłodowskiej-Curie.

Ware, J., \& Sherbourne, C. (1992). The MOS 36-item short-form health survey 1: Conceptual framework and item selection. Medicine Care, 30, 473483. 